\title{
EXCHANGE RATE AS AN INSTRUMENT OF ECONOMIC POLICY - EXPERIENCE OF EASTERN ASIA COUNTRIES
}

\author{
Natasa Milenkovic* \\ Graduate School of International Economics, Megatrend University, Belgrade, Serbia
}

The main driver of growth in virtually all economies that have achieved rapid growth in recent decades, especially Asian economies, were investment and exports. There is a general agreement that export expansion represents the most effective way for Serbia's economic recovery. The experience of Asian countries, those with rapid growth, can provide guidelines on how the precarious condition of the Serbian economy can be improved to a certain extent. The exchange rate is an instrument of the economic policy that simultaneously affects both the investment and exports of a country, and is the one easier to run than many other factors of growth and development. Several indicators indicate the importance of the exchange rate as an instrument of the economic policy in increasing exports and investments in Serbia. These are, first, the extremely positive experiences of Eastern Asia economies, whose exchange rate policies are the opposite to that of Serbia, the weakness of the domestic market, indicating the necessity of an increase in exports, and thirdly, the extremely low competitiveness of the Serbian enterprises and its economy.

Keywords: exchange rate, foreign trade, competitiveness, economic growth, Serbian economy

JEL Classification: E42, E52, 024

\section{INTRODUCTION}

Among the numerous factors credited for the outstanding success of Eastern Asia economies, in the opinion of most analysts, investment and exports are the most important ones. They are often referred to as "growth locomotives" or "engines of growth" because they have the power to start the entire economy. Such opinions are not based only on the empirical fact that

\footnotetext{
* Correspondence to: N. Milenkovic, Graduate School of International Economics, Megatrend University in Belgrade, Bulevar umetnosti 29, 11000 Belgrade, Serbia; e-mail: natasa712004@yahoo.com
}

the Eastern Asia countries have achieved tremendous economic growth simultaneously with the growth in exports and investments; moreover, there are theoretical arguments in support of this thesis. Namely, a high rate of investments indicates an increased equity, and the latter may permanently increase the rate of growth through economies of scale. In the case of exports, the theoretical argument is that an export orientation increases the openness of an economy, which makes it more open to the penetration of new technologies and foreign competition, leading to an acceleration of technological progress.

Bearing in mind that foreign trade is one of the weakest points of the Serbian economy, there is no 
doubt that, similarly to the Eastern Asia countries, Serbia's economic recovery can most effectively be accelerated by the expansion of exports. In support of this thesis goes the fact that, compared to the majority of the Asian countries, Serbia is a small country and its long-term growth cannot be based exclusively on the sale of goods on the domestic market. Besides, without an additional foreign exchange influx, current growth cannot be maintained.

The main hypothesis is that, according to the experience of Eastern Asia countries, especially the experience of China during the period of continuous export growth and economic growth, the currency policy could be a very important instrument of an economic policy for boosting exports and improving the export position of Serbia.

The studies of the impact of the exchange rate policy on economic growth had a significant momentum in the 1980's, when they were stimulated by the rapid growth of Eastern Asia economies; this growth was largely based on exports, while exports were based on competitiveness due to the low value of the domestic currencies. In the last few years, there has been a new interest in the impact of the exchange rate on economic growth among scholars.

This paper aims to scientifically explain the exchange rate impact on export growth, and thus, indirectly, on the acceleration of economic growth. The explanation of this instrument of the economic policy has been presented theoretically and empirically, particularly emphasizing the experiences of the countries of Eastern Asia, as the most successful examples of this influence.

By comparing the exchange rate policy in Serbia with those in Eastern Asia countries, with an emphasis on the differences between and even contradictions in the approaches to the instrument, this paper emphasizes the need for changes in the exchange rate policy in Serbia. Without neglecting the significant limitations of the exchange rate policy as an instrument, it is certain that its application may influence many weaknesses of the Serbian exports.

\section{THE INFLUENCE OF THE EXCHANGE RATE ON ECONOMIC GROWTH}

\section{Theoretical approach}

The exchange rate affects the economy of a country in many ways, and makes a variety of macroeconomic and development effects. Frenkel and Taylor $(2006,1)$ allocated the areas in which the exchange rate has the biggest impact on developing countries and countries in transition. These are:

- Allocation of resources: The exchange rate has a significant influence on the allocation of resources in a society by affecting the price level. As it simultaneously affects the allocation of resources and the overall demand, a relatively low rate may contribute to an increase in employment.

- Economic Development: A relatively low exchange rate, with an adequate industrial and foreign trade policy, increases competitiveness, thus creating the conditions necessary for increasing productivity and economic growth.

- Finance: The exchange rate itself significantly affects the expectations and behavior of the financial market, which means it can be used as a mechanism for its control and stabilization.

- External balance: The trade and other components of the current account usually respond to a large extent on the relative price of foreign goods and services in relation to domestic ones, or the real exchange rate.

- Inflation: The exchange rate may have a role as an anchor, by holding prices at a relatively low level through appreciation (the overestimation of the local currency), and by holding the currency in a stronger position than it is real.

The exchange rate has the most direct impact on the economic growth of a country through its influence on foreign trade. The hypothesis of an economic growth based on exports sees the export expansion as one of the most important determinants of the growth based on technological acceleration. One of the ways in which foreign trade drives growth is by technological 
progress, which is the natural consequence of the international exchange. When a country is open to international trade and competes on the global market, it is natural for it to adopt the most advanced production technologies and management techniques, engage the most qualified human resources, and invest in sophisticated research and development (R\&D). Increasing efficiency in terms of the costs and volume, we can improve the factors of production - labor and capital.

The real exchange rate is a good indicator of a country's export competitiveness, showing the relation between the price of goods and services in one country compared to prices in other countries. The undervaluation of the domestic currency is a situation where the nominal exchange rate is above the real one, in which case we are talking about a real depreciation. In the case of the undervalued exchange rate purchasing power in a country is higher than abroad. Due to the high cost of foreign currencies, the price of imports increases, which further leads to the growth of domestic demand and declining demand for imported products. Exporters get more local currency, which increases products export and the competitiveness on foreign markets. These trends result in the improvement of the balance of payments. According to traditional Keynesian macroeconomics, relative depreciation stimulates exports, making them more profitable, which in turn encourages companies to increase the volume of their exports. Since the demand for exports is relatively elastic with respect to prices, increasing the volume of exports leads to an increase in export earnings, and thus to an increase in total income and employment.

Conversely, if the exchange rate is below the level of the real exchange rate, a local currency is overvalued (appreciation), and a foreign one is underestimated. The overvaluation of the local currency means a higher purchasing power abroad than at home. Foreign goods' prices, denominated in the local currency at such a rate, become lower, so there is interest in importing goods, because imports become relatively inexpensive. Foreign goods, which would be too expensive for the average consumer at the real exchange rate, become more competitive in the domestic market at the lower exchange rate, which, naturally, leads to reduced domestic production. Conversely, products that the given economy could export at the real exchange rate become too expensive, i.e. uncompetitive in the international market.

The overvalued exchange rate makes domestic consumers and producers rely on imports but has a strong negative effect on the export capacities of the given economy. Over time, imports exceed exports, which contributes to the draining of foreign currencies. This, further, leads to the lower and lower ability of buying goods from abroad, and severely increases the inability of paying credits for the servicing of the foreign debt.

The ultimate effect of the overvalued exchange rate is that the given state loses the earlier comparative advantage it had because of the lower price of export products from rival exporters. Of course, the comparative advantage of export does not have to reflect in lower prices. It can be reflected in a better quality, or a technologically more advanced manufacturing process. However, this is the advantage developed countries can count on, while in the case of developing countries, for the majority of products, a low price is a major advantage.

Even in countries where the direct impact of exports on the aggregate GDP is relatively small, it has an immense positive impact on other components of growth, such as investment and spending increase.

Exchange rate management can have a strong impact on the overall savings, because it affects consumption and investments by establishing real wages. The low price of a foreign currency makes borrowing in such a foreign currency relatively cheap, leading to the overindebtedness of the country abroad, and of its citizens with banks.

The export earnings themselves, which, on the one hand, are extremely desirable for any economy, sometimes, on the other hand, encourage the overstatement - appreciation of the exchange rate. The retention of this overvalued exchange rate may result in restraining economic growth.

The common negative effect of the appreciation as well as the one of the depreciation of the local currency sends the wrong signals to investors about the areas in which to invest. In the case of the overvalued local currency, the production relying on imported raw 
materials seems more profitable than it really is. On the other hand, the undercount of the national currency, due to the unrealistic increase in the price of imports, sends signals that it should be invested in sectors that may otherwise be profitable only in terms of an unrealistically high exchange rate.

The appreciation is always good for collecting political points, because it reduces the prices of imported products and has an anti-inflation effect. However, for the reasons discussed above, it can have devastating effects on the allocation of resources and prospects for development. In addition, as first described by Frankel in 1983, (Frenkel \& Taylor, 2006, 7), a fixed or quasi-fixed strong exchange rate can easily induce the destabilization of the capital movements cycle.

\section{Empirical Research}

The empirical investigation of the impact of depreciation on export earnings gives different results. Some of them show a clear and direct correlation, or a positive effect, while others argue that this correlation does not exist. On the other hand, the research of the correlation between the exchange rate and economic growth shows a significant connection.

A significant empirical research of the impact of the debt crisis in Latin America and Eastern Asia countries was conducted by Sachs in the early nineteen-eighties (1985, 523-573). His conclusion was that the Asian countries more successfully had overcome the crisis specifically because of a better exchange rate regime and a better foreign trade policy. Except for the Philippines, none of the successful Asian economies has an external debt problem.

Numerous recent studies have offered a lot of evidence that the exchange rate has a significant impact on production growth. One of the most important ones is a comprehensive study by Hausmann et al. (2005), which comprised more than 80 cases of sustained growth since the 1950s (i.e. the rapid growth that has lasted for more than eight years), than, further, studies by Razmi (2007), Berg et al. (2008), Blecker and Razmi (2009) and other studies.

Blecker and Razmi (2009) approached this problem by developing a separate index of the exchange rate for each exporting developing country in relation to:
- the currencies of the industrialized countries and

- the currencies of competing developing exporters.

Using the panel data method, they found that the real depreciation of a currency in relation to the developed countries generally gave contraction effects, while the real depreciation in relation to the competing developing countries had a strong expansionary impact on output growth.

All the above-mentioned empirical studies demonstrate a statistically significant role of competitive exchange rates, as one of several factors strongly associated with the continued growth of the analyzed economies.

What regularly appears in empirical research is the relative undercount of exchange rates in Asian countries in the period from 1970 to 2000 . In most papers, the low value of the domestic currency in Asian developing countries appears as a regional pattern.

\section{ASIAN COUNTRIES EXPERIENCE}

There is no doubt that trade is an integral part of the model of growth in developing countries. During the 20th century, there was an expansion of foreign trade, which led to the growth of employment and generated wealth, and then, further, to a drastic improvement in living standards around the world. In the mid-20th century, many developing countries in Asia, such as South Korea and Taiwan, successfully adopted a strategy of growth based on exports, achieved financial balance and improved productivity.

Over the last 30 years, the competitive value of Asian currencies has been, one of the most important factors of the successful growth of East- and Southeast Asia countries. Reliance on a strategy of export-oriented manufacturing growth has, in many cases, led to an outstanding business success. Thanks to this strategy, during the period 1960-1980, the region of East and Southeast Asia achieved far higher growth than other regions of the world (Table 1), excluding the Middle East, which made an unusually high rate of growth based on a sudden increase in the oil prices in the 1970s. As can be seen from the data accounted for in Table 1, the growth of Eastern Asia economies in this period was $6.6 \%$, while in developed countries it was 
only $4.5 \%$, which was the world average. Growth based on exports continued to the end of the 20th century, although in the last two decades, South Asia, specifically India, has been achieving higher rates of economic growth.

Table 1 GDP growth in the regions of the world 1960-2012

\begin{tabular}{lccc}
\hline & $1961-1980$ & $1981-2000$ & $2001-2011$ \\
\cline { 2 - 4 } East Asia & 6.6 & 4.1 & 3.6 \\
Developed countries & 4.5 & 3 & 1.6 \\
Latin America & 5.5 & 2.3 & 3.4 \\
MENA & 8.7 & 3.0 & 4.4 \\
South Asia & 3.7 & 5.4 & 6.9 \\
The World & 4.6 & 3.1 & 2.5 \\
\hline
\end{tabular}

Source: Author, according to the World Bank (http://databank. worldbank.org)

The most successfulexport strategies were implemented in the so-called Asian Tigers, which include South Korea, Taiwan, Hong Kong and Singapore, in the 1970s and the 1980s. The rise of the Asian Tigers: Hong Kong, Singapore, South Korea and Taiwan, had started in the 1960s, with the development of the industrial base and by focusing on international trade. Their production, compared to developed countries, had had a significant advantage, due to the relatively low wages. Thus, the initial stage of their boom was marked by the export of cheap low quality products into huge trading partners, Japan and the United States. With the help of high investments (domestic and foreign), and an increase in labor productivity, these economies achieved a better quality of goods over time, but they continued to rely on their most important competitive advantage - the low cost of products. In some cases, the Asian Tigers used mechanisms such as trade barriers, the exchange rate control, as well as other forms of the government intervention to boost foreign trade as a major pillar of their economic development.

Their growth began to decline in the 1990s, and China and India assumed the leading role among the Asian countries in terms of the GDP growth rates. In the 1990s, these two countries took advantage of the relatively low exchange rates, which incited exports and output growth.

In the region of Eastern Asia, which has been achieving rapid growth for decades, the Chinese economy growth of $11 \%$ on average has been the most rapid one in the last decade (Table 2). China's economy has mainly been managed by using traditional macroeconomic instruments such as the monetary policy and the exchange rate policy. China's exchange rate policy is the subject of much international attention, but also a source of pressure, because many believe that, currently, it contributes to an increase in global imbalances.

Table 2 The growth rate of the economies of East and Southeast Asia, 1960-2009

\begin{tabular}{lcccccccc}
\hline & \multicolumn{1}{c}{ (GDP growth in \%) } \\
\cline { 2 - 8 } China & $1960-1980$ & $1980-2002$ & $2003-2006$ & 2007 & 2008 & 2009 & 2010 & 2011 \\
\cline { 2 - 8 } Hong Kong & 4.9 & 9.5 & 11 & 14.2 & 9.6 & 9.1 & 10.4 & 9.3 \\
Indonesia & 9.5 & 5.1 & 8.4 & 6.4 & 2.2 & -2.8 & 7.0 & 5.2 \\
Japan & 6.0 & 5.1 & 5.3 & 6.3 & 6.0 & 4.5 & 6.2 & 6.5 \\
Korea & 7.4 & 2.4 & 2.0 & 2.4 & -1.2 & -5.2 & 4.4 & -0.7 \\
Malaysia & 7.8 & 7.1 & 4.1 & 5.1 & 2.3 & 0.2 & 6,3 & 3,6 \\
Singapore & 7.2 & 6.1 & 5.8 & 6.5 & 4.7 & -1.7 & 7.2 & 5.1 \\
Thailand & 9.3 & 6.8 & 8.8 & 8.5 & 1.8 & -1.3 & 14.8 & 4.9 \\
\hline
\end{tabular}

Source: Author, according to the World Bank (http://databank.worldbank.org) 
China's share in world trade has rapidly increased in recent years. It is the largest exporter in the world, and its share in the total world exports continues to increase. In 2010, it amounted to more than $10.4 \%$ of the world exports (WTO, World Trade Report 2012, 23). In 2011, the Chinese export with a growth rate of 9.3\% was the second fastest-growing one in the world, after the Indian one (WTO, World Trade Report 2012, 21).

China's exchange rate policy consists in maintaining the artificially low exchange rate of Yuan, with the aim of realizing profits from foreign demand and achieving high growth rates.

Since the beginning of the economic reform in 1978, there have been several adjustments of the Yuan exchange rate (Graph 1). In January 1981, the government halved the value of the Yuan in trade transactions, by introducing the internal rate of 2.8 Yuan against the U.S. dollar, while the official rate remained at 1.5. From January 1981 until late 1984, the authorities gradually depreciated the official rate, until it reached 2.8, when the internal rate was abolished. However, the government continued to gradually devalue the official exchange rate, which reached 3.2 by the middle of the 1986. In July 1986, the authorities continued to reduce the value of the currency by 15 percent, and the rate reached 3.7 Yuan against the U.S. dollar.

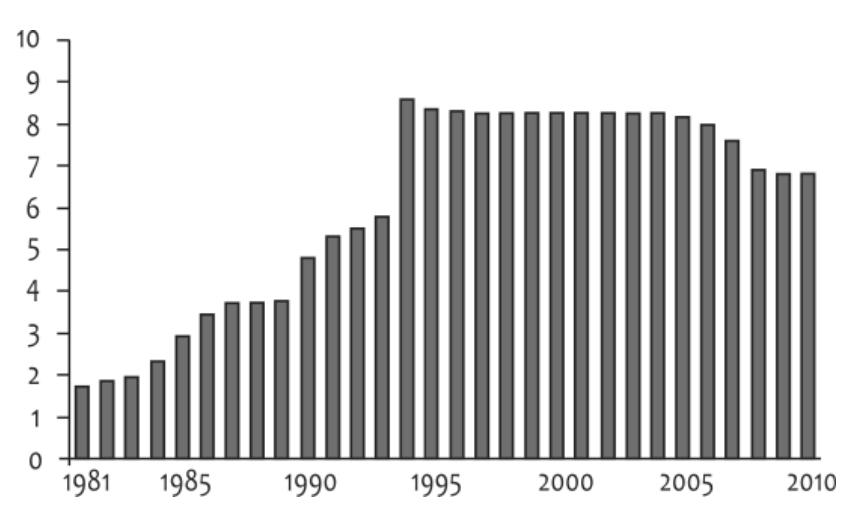

Graph 1 RMB middle exchange rate annual average

Source: Author, according People's Bank of China (www.pbc. gov.cn/publish)
In late 1989, the authorities again significantly devalued the official exchange rate, this time by as much as 21.2 percent. The government, then, made a few minor adjustments in the official rate. Later, in January 1994, the government unified the two rates, and the market price of 8.7 Yuan against the dollar prevailed. Since the unification, the Yuan reached a record value of 8.28 against the U.S. dollar by the middle of the year 1995, and that value has declined to 6.5 Yuan against one U.S. dollar up to date.

The exchange rate issue is becoming a growing source of antagonism at the global level. The U.S. and the European Union have criticized China for the maintenance of the depressed value of the Yuan at an undervalued level by up to $40 \%$ against the dollar. The issue, which threatens to cause a trade war, was at the top of the agenda at the Summit of finance ministers and central bank governors of the G 20, held in Seoul in November 2010. However, the leaders of the Group of 20 largest world economies refused to support the U.S. pressure on China to allow the rise of the value of its currency. At the end of the Summit, the heads of the Group of 20 issued a moderate press release, pleading for refraining from the "competitive devaluation" of currencies.

The U.S. officials claim that a more expensive Yuan would make Chinese exports more expensive and American goods cheaper in China. That would reduce the constant U.S. problem of trade deficit with China. According to the data from the U.S. Census Bureau (2010), in the year 2010, the U.S. trade deficit with China amounted to 273 billion U.S. dollars, which is a new record after the one of 268 billion dollars in the year 2008. According to the same source, the deficit had exceeded 100 billion U.S. dollars already in 2002, and it has been growing at an incredible rate since then, which, according to a general opinion, is a direct result of the undervalued Yuan rate. Washington did not obtain support for the criticism of China, probably because the U.S. has been pursuing the same policy of the domestic currency devaluation since the Great Depression of 2009. Namely, following the decisions of the U.S. Federal Reserve, the additional amounts of several hundred billion dollars are constantly fed into the slow U.S. economy. In this way, the market is 
stuffed with dollars, which diminishes the value of the American money and favors the U.S. exporters.

Another fact corroborating the hypothesis of a positive impact of maintaining the value of the local currency at a low level is the experience of the Asian countries with the consequences of the Asian crisis of 1997. Those countries that less intensively defended their currency by interventions in foreign exchange reserves during the Asian crisis of 1997, ended up with the smaller depreciation of the national currency and, of course, less reduction in the foreign exchange reserves than it was the case with those central banks that did so at any cost.

\section{FOREIGN TRADE FEATURES AND EXCHANGE RATE POLICIES IN SERBIA}

The main features of the state of the economic relations between Serbia and abroad are the enormous growth of the external debt and a high foreign trade and balance of payments deficit, which continues to rise.

In 2008, the imports of Serbia were two times higher than exports. In that year, according to the data of the Republic of Serbia Statistical Office (2011), the total foreign trade amounted to nearly 34 billion dollars, and the value of goods exported was only 11 billion. Although the global economic crisis has not led to a trade deficit, it has caused a drastic drop in imports from the most important trade partners of Serbia, which has contributed to the further enlarged deficit, in terms of percentage. In 2009 and 2010, the deficit was gradually reduced, but the total exports further reduced.

According to the data of the Statistical Office, the crisis of Serbian exports has been lasting for a much longer time period. In the last ten years, the deficit increased from 1.75 to as much as 11.9 billion USD in 2008, only to drop to about 7 billion USD in 2009 and 2010, and again increase to over 8 billion USD in 2011, which accounted for a deficit of about $16 \%$. The growing foreign trade deficit is a reflection of the enormous increase in imports and the low growth of exports over the past five years. According to the analysis of the Statistical Office, a certain increase in exports and a decrease in the deficit in 2010, compared to 2009, are the result of the export of the ferrous and non-ferrous metallurgy, as well as the export of agricultural products, and of a mild depreciation of the dinar, too, which occurred in 2010.

Table 3 Foreign trade of Serbia in the period 1999 - 2011

\begin{tabular}{lrrr}
\hline Year & & \multicolumn{2}{c}{ (in millions USD) } \\
\hline 1999 & Exports & Imports & Balance \\
2000 & 1369 & 2881 & -1512 \\
2001 & 1558 & 3330 & -1772 \\
2002 & 1721 & 4261 & -2540 \\
2003 & 2075 & 5614 & -3539 \\
2004 & 2755 & 7473 & -4718 \\
2005 & 3523 & 10753 & -7230 \\
2006 & 4482 & 10461 & -5979 \\
2007 & 6428 & 13172 & -6744 \\
2008 & 8825 & 18554 & -9729 \\
2009 & 10973 & 22875 & -11902 \\
2010 & 8344 & 16056 & -7712 \\
2011 & 9,794 & 16,735 & $-6,941$ \\
\hline
\end{tabular}

Source: Republic of Serbia Statistical Office, 2011

In terms of trade with certain regions, the largest deficit, although together with the largest volume of exports, was recorded in trade with developed countries - 988 million USD, then with transition countries, 859 million USD, while with the developing countries, it amounted to a 131 million USD deficit. Such a structure of the export markets, and the fact that we have the largest deficit with developed countries, confirms the assumption about the negative effects of the overvaluation of the national currency in Serbia. Imports in Serbia have become relatively inexpensive.

According to the comprehensive study Competitiveness of Serbian economy (Konkurentnost privrede Srbije, Jefferson Institute, 2006, 1), based on several studies conducted, Serbia is able to generate significantly more exports than it currently does. According to the results of this study, all the reasons for that delay can 
be reduced to a common denominator, which is the lack of competitiveness. The Serbian economy is not competitive, not only compared to the EU, but to the neighboring countries as well. The research comprised the total of 76 countries, and Serbia was ranked 69th according to the competitiveness of its economy.

The policy of strengthening competitiveness cannot be separated from the exchange rate policy, which, in addition to the previously mentioned, is another motive to examine the range and capabilities of this instrument of the economic policy.

In Serbia, there has always been a tendency to have a fixed nominal exchange rate policy. The practice of many countries, confirmed by numerous empirical studies, shows that the fixed nominal exchange rate only provides short-term results, while afterwards all the negative effects of the national currency appreciation appear - such as a balance of payments deficit and the excessive borrowing of the country. Under inflationary conditions the "fixed exchange rate becomes enormously unrealistic, foreign currencies become undervalued and the dinar overvalued, which erases all the attempts of companies to remain competitive in the export and domestic markets." (Kovač, 2006, 15)

After the political change of 2000, Serbia has to some extent abandoned the fixed exchange rate system, which at that time was incredibly unrealistic 6 dinars against the German mark. The exchange rate was then increased to 30 dinars for the mark. It should be emphasized that even then the exchange rate was not left to the market. For a certain period, it was also fixed, only on more realistic values. After October 5th, 2000, the National Bank of Serbia (still Yugoslavia at that time) used the exchange rate to achieve the macroeconomic stability and inflation reduction, following the recommendation of the International Monetary Fund. In good part, this proved to be successful.

Compared to the year 2000, "the real effective exchange rate enormously appreciated in 2001 and 2002" (Kovač, 2006, 16). The introduction of the New Economic Policy in the year 2001 constantly led to the overvaluation of the domestic currency. Since 2003, at least nominally, the managed floating exchange rate regime has been in force. This model presumes the market-determined exchange rate, and a float managed in terms of an occasional interference of the monetary authorities in the foreign exchange market trends.

However, although the model of the managed floating exchange rate has in the past period been the closest to the Serbian one, we clearly notice the frequent interventions of the National Bank of Serbia in order to maintain the current value of the dinar. In this manner, it takes on certain characteristics (adverse effects) of a fixed model.

The monetary authorities should not react to defend a certain parity; instead, they should relatively rarely intervene to limit excessive destabilizing fluctuations in exchange rates. "The managed fluctuation of the national currency in the foreign exchange market does not imply the existence of a pre-announced target value of the exchange rate, and there is no need for monetary authorities to accumulate foreign exchange reserves and to intervene in the foreign exchange market. Therefore, the lack of targets for speculative attacks leads to the lesser likelihood of currency crises" (Beker, 2006, 31-49).

According to the official view of the economic policy in Serbia, the exchange rate is not the cause of high external deficits, and the nominal exchange rate is still considered to be an anchor to control inflation (this attitude is imposed by international economic and financial organizations), regardless of its large real appreciation.

Empirical research suggests otherwise. The Dinar is still constantly overrated. The growth of the domestic prices is constantly greater than the change of the dinar rate against the dollar and the euro. "It was only in the year 2004 that there was a mild real depreciation unable to correct the immense accumulated appreciation. At the end of March 2005, this cumulative appreciation amounted to 53.48\%" (Kovač, 2006, 16). According to a comprehensive study, the "Macroeconometric modeling of the Serbian economy - the theoretical basis and the results" (CES MECON, 2005), the real appreciation of the dinar during this period was mainly caused by an increase in imports, and to a lesser extent an increase in production. Center for Economic Studies Mecon joined the econometric 
testing of imports to Serbia, which showed that the level of imports was significantly affected by the movement of the real exchange rate, real wages and industrial production. The testing of the imports showed that, in the stabilization period, the exchange rate was a significant factor in the growth of imports, and, consequently, in the trade deficit of Serbia.

More recent analyses also suggest that the constantly overvalued exchange rate is one of the major causes of "a massive trade deficit and the growing debt of citizens, businesses and the state..." (Jovović, 2011, 66). In the first half of 2011, the dinar appreciated by $3 \%$ against the euro and $12 \%$ against the U.S. dollar (Jovović, 2009, 74). In April 2011, the value of the dinar fell to below 100 dinars against the euro, to the level from a year ago. The appreciation of the dinar constantly keeps going on, without real coverage or without an adequate inflow of export-generated foreign exchange. "It is impossible to have a strong dinar in a weak economy with low export..." (Jovović, 2011, 68). This can mainly be attributed to more NBS intervention in the election year.

The overvalued exchange rate and import liberalization stifle local production, which again encourages the growth of imports. The aim of imports liberalization was to encourage the import of new technologies and equipment that would improve and instigate production in Serbia. Unfortunately, instead of strengthening the competitiveness of domestic products in foreign markets, liberalized imports have led to the increased competitiveness of foreign goods in the domestic market, which has led to the closure of a number of companies.

Another mentioned weakness of the overvalued national currency - excessive borrowing, has also emerged in Serbia. The indebtedness of the private sector is a consequence of the great appreciation of the rate of the dinar and its external value being much higher than the internal one. The largest debt was incurred at the time of the highest appreciation in the years 2005-2008. By the end of this period, the rate had reached 88.6 dinars for one euro, as a result of the events in the foreign exchange market at the end of the year. According to the Association of Serbian Banks (The Association of Serbian Banks, Press
Conference 18/09/2012), at the end of 2011, the total of $11.8 \%$ of borrowers (households, entrepreneurs and legal entities) who had taken loans from banks were late with repayment. In most cases, the reason was the large depreciation of the dinar against the euro (from 79 dinars for one euro in 2007 to 116 for 1 euro in 2012).

Based on the results of the aforementioned econometric modeling, it follows that the appreciation of the real exchange rate and excessive growth in domestic demand have also been the main drivers of the increase in imports and the trade deficit since early 2001.

The econometric finding that the growth of imports and the foreign trade deficit caused the expansion of domestic demand, which has for several years been by $20-25 \%$ beyond the production in Serbia and still growing, which is not sustainable in the long term, is also greatly significant.

Due to the relatively high exchange rate, Serbian products are uncompetitive in exports in the price terms, while demand for imported products is higher than agreeable with the capabilities of the Serbian economy. The NBS has until recently emphasized that its primary goal is to preserve inflation, although it is known that the stable value of the national currency has to be the result of a stable economy, and that the growth of the economy has to be the result of productivity growth, not the result of spending foreign exchange reserves. To make matters worse, the dinar rate has, until now, been largely defended by the borrowed funds. Namely, the maintenance of the dinar at a given level is a consequence of the frequent intervention of the NBS with the funds from the foreign exchange reserves, which are the result of privatization, and borrowing from the outside, not the result of the export of goods and services.

\section{CONCLUSION}

Several indicators point out the significance of the exchange rate as an instrument of the economic policy to increase exports and investments in Serbia. This paper points out the highly positive experiences of Eastern Asia economies, whose exchange rate policy 
is the opposite to that of Serbia. An additional reason for the export-oriented development strategy is the weakness of the already-too-small a domestic market. Third, the factor representing the most serious obstacle for the export is the extremely low competitiveness of Serbian companies and the economy.

The strategy of increasing the competitiveness of the Serbian economy should be based on the market value of the exchange rate. A Real or slightly depressed exchange rate would encourage the competitiveness of exporters and possibly instigate the development of new product lines, which, in terms of an overvalued exchange rate, has no economic justification.

In order to create a competitive foreign exchange market and form a foreign exchange rate which would be the result of the real market conditions, the reduction of the role of the National Bank of Serbia in the foreign exchange market is necessary. This would mean abandoning the previous policy of the exchange rate stability, given that this way of defending the dinar is extremely expensive, since it consumes the foreign exchange reserves and leads to further borrowing. In that case, the NBS would intervene in the foreign exchange market only occasionally, when it is necessary to prevent extreme fluctuations in the exchange rate. The NBS should take responsibility for the inflation moving within certain limits, while the determination of the exchange rate should be left to the market.

Today, Serbia has a managed floating exchange rate, which, in the opinions of the majority of domestic and foreign analysts, is probably the best solution. There are supporters of free-floating and fixed exchange rates, but these represent a significant minority. Most of them understand that both extremes have many weaknesses, which Serbia, with its weakened economy, would hardly handle.

The fixed exchange rate would bring lower interest rates, fewer risks and fewer uncertainties regarding business, but it would exhaust the Serbian foreign reserves. On the other hand, a completely free exchange rate would lead to a (real) decline of the dinar, which, in a certain period, would most surely lead to a significant increase in exports, but the consequences for businesses and citizens with loans related to the euro would be disastrous.

The exchange rate would have to be as close to its real value as possible, and any deviation from the real value would have to tend to the underestimation rather than overestimation of the dinar, which would stimulate exports, as only export expansion can make Serbia overcome the crisis.

Along with releasing the intervention of the National Bank, because of a possible decline of the dinar in the future, the problem of huge foreign exchange loans to individuals and businesses should be solved. All the subjects - borrowers, commercial banks, the state officials, and the National Bank of Serbia - should take part in finding a solution.

\section{ACKNOWLEDGEMENTS}

The research in this paper was conducted within Project No. 47004, funded by the Ministry of Science of the Republic of Serbia.

\section{REFERENCES}

Beker, E. (2006). Devizno-kursni aranžmani - od ekstrema do "normale". Panoeconomicus, 53(1), 31-49.

Berg, A., Ostry, J., \& Zettelmeyer, J. (2008). What makes growth sustained? IMF, Working Paper, Series 08/59.

Blecker, R., \& Razmi, A. (2009). Export-led growth, real exchange rates and the fallacy of composition. Handbook of Alternative Theories of Economic Growth. Northampton.

Frenkel, R., \& Taylor, L. (2006). Real exchange rate, monetary policy and employment. United Nations. New York: Desa Working Paper, No 19.

Hausmann, R., \& Eichengreen, B. (2005). Other People's Money: Debt Denomination and Financial Instability in Emerging Market Economies. Chicago: University of Chicago Press.

Jovović, M. (2011). Dinar i režim deviznog kursa. Bankarstvo, $11-12,56-81$.

Jefferson Institute. (2006). Konkurentnost privrede Srbije. 
Kovač, O. (2006). Konkurentnost i politika deviznog kursa u Srbiji. Megatrend revija, 3(1).

CES Mecon. (2005). Macroeconometric Modeling of Serbia's Economy: Theoretical Basis and Results. Beograd.

Razmi, A. (2007). The contractionary short-run effects of nominal devaluation in developing countries: some neglected nuances. International Review of Applied Economics, 21(5), 577-602. Pristupljeno 23.12.2011, http://works.bepress. com/arslan_razmi/4/

Sachs, J. (1985). External debt and macroeconomic performance in Latin America and East Asia. Harvard University, Brookings Papers on Economic Activity. 2, 523-573.

SIEPA. (2010). Invest in Serbia. Beograd.

Učešće docnje $\mathrm{u}$ dugu po osnovu bankarskih kredita. Udruženje banaka Srbije. Pristupljeno 24.09.2012, http:// www.ubs-asb.com/Portals/0/vesti/113/18-09-12-5.pdf
World Trade Report 2012. (2012). WTO.

IMF. World Economic Outlook 2008. Pristupljeno 18.03.2012, www.imf.org/external/pubs/ft/weo/2008/02

People's Bank of China. Pristupljeno 14.05.2011, www.pbc.gov. cn/publish/english/984/index.html

U.S. Census Bureau. Pristupljeno 14.05.2011, www.census.gov/ foreign-trade/balance/c5700.html\#2010

World Bank. Pristupano 14.08.-30.12.2011, www.worldbank. org/

World Trade Report 2012. Pristupljeno 21.09.2012, http://stat. wto.org/CountryProfile

Zavod za statistiku Republike Srbije. Pristupljeno 16.05.2011, webrzs.stat.gov.rs/

Received on $25^{\text {th }}$ August 2012, after one revision, accepted for publication on $12^{\text {th }}$ December 2012

Natasa Milenkovic is an associate professor at the Graduate School of International Economics, Megatrend University, Belgrade, Serbia. She has been teaching the Economics of Asia and Russia. She has published two books, fifteen scientific papers and has participated in several conferences in the country and abroad. 


\title{
DEVIZNI KURS KAO INSTRUMENT EKONOMSKE POLITIKE - ISKUSTVA ZEMALJA ISTOČNE AZIJE
}

\author{
Nataša Milenković* \\ Fakultet za međunarodnu ekonomiju Megatrend univerziteta u Beogradu
}

\begin{abstract}
Glavni pokretači rasta bezmalo svih privreda koje su u proteklim decenijama ostvarile brz rast, pre svega azijskih privreda, bili su investicije i izvoz. Postoji opšta saglasnost da je najefikasniji put ka privrednom oporavku Srbije, takođe, izvozna ekspanzija. Iskustva azijskih zemalja sa ubrzanim rastom mogu dati smernice za način na koji je moguće, u izvesnoj meri, poboljšati nezavidno stanje srpske privrede. Instrument ekonomske politike koji utiče istovremeno na investicije i izvoz jedne zemlje, a koji je lakše pokrenuti od mnogih drugih faktora rasta i razvoja, je devizni kurs. Na značaj deviznog kursa kao instrumenta ekonomske politike za povećanje izvoza i investicija u Srbiji upućuje nekoliko indikatora. To su, najpre, izuzetno pozitivna iskustva istočnoazijskih privreda čija je politika deviznog kursa upravo suprotna onoj u Srbiji, slabost domaćeg tržišta, koja ukazuje na neophodnost povećanja izvoza i, treće, izuzetno mala konkurentnost srpskih preduzeća i privrede.
\end{abstract}

Ključne reči: devizni kurs, spoljna trgovina, konkurentnost, ekonomski rast, srpska privreda

JEL Classification: E42, E52, O24

\section{UVOD}

Među brojnim faktorima kojima se pripisuju zasluge za izuzetan uspeh istočnoazijskih privreda, po oceni većine analitičara, najznačajniji su investicije i izvoz. Često se nazivaju "lokomotivama rasta" ili "motorima rasta", jer imaju dovoljno snage da iniciraju pokretanje čitave privrede. Ovakva mišljenja zasnivaju se ne samo na empirijskoj činjenici da su istočnoazijske zemlje ostvarile neverovatan privredni rast istovremeno sa rastom izvoza i investicija, već postoje i teorijski

\footnotetext{
* Korespondencija: N. Milenković, Fakultet za međunarodnu ekonomiju Megatrend univerziteta u Beogradu, Bulevar umetnosti 29, 11000 Beograd, Srbija; e-mail: natasa712004@yahoo.com
}

argumenti $\mathrm{u}$ prilog ovoj tezi. Naime, visoka stopa investicija znači da je povećan uloženi kapital, a to može trajno da poveća stopu rasta kroz ekonomiju obima. U slučaju izvoza, teorijski argument je da izvozna orijentacija povećava otvorenost privrede, koja tako postaje izloženija prodoru novih tehnologija i strane konkurencije, što dovodi do ubrzanja tehnološkog napretka.

Imajući u vidu da je spoljna trgovina upravo jedna od najslabijih tačaka srpske privrede, nema sumnje da, slično istočnoazijskim državama, privredni oporavak Srbije najefikasnije može ubrzati izvozna ekspanzija. U prilog ovoj tezi ide i činjenica da je Srbija, u odnosu na većinu azijskih zemalja, mala zemlja, te se njen dugoročni rast ne može zasnivati samo na plasmanu 
robe na domaće tržište. Uz to, bez dodatnog deviznog priliva ne može se očekivati ni održanje postojećeg rasta.

Osnovna hipoteza je da bi, prema iskustvima zemalja Istočne Azije, posebno Kine u periodu kontinuiranog rasta izvoza i privrednog rasta, veoma važan instrument ekonomske politike za podsticanje izvoza i poboljšanje izvozne pozicije Srbije mogla da predstavlja politika deviznog kursa.

Istraživanja o uticaju politike deviznog kursa na ekonomski rast imala su značajan zamah osamdesetih godina prošlog veka, kada su bila podstaknuta naglim rastom istočnoazijskih privreda koji je $\mathrm{u}$ velikoj meri bio zasnovan na izvozu, a ovaj na konkurentnosti zahvaljujući niskoj vrednosti domaćih valuta. Poslednjih nekoliko godina dolazi do obnove interesovanja naučnika za uticaj deviznog kursa na ekonomski rast.

Cilj rada je naučno objašnjenje uticaja politike deviznog kursa na rast izvoza, time posredno i na ubrzanje ekonomskog rasta. Objašnjenju ovog instrumenta ekonomske politiske pristupa se teorijski, ali i empirjiski, posebno se zadržavajući na iskustvima zemalja Istočne Azije, kao najuspešnijeg primera ovog uticaja.

Komparacijom politike deviznog kursa u Srbiji sa onim u zemljama Istočne Azije, sa naglaskom na razlike, čak suprotnosti u pristupu ovom instrumentu, rad stavlja naglasak na neophodnost izmena u politici deviznog kursa u Srbiji. Ne zanemarujući značajna ograničenja politike deviznog kursa kao instrumenta, izvesno je da se njegovom primenom može uticati na brojne slabosti srpskog izvoza.

\section{UTICAJ DEVIZNOG KURSA NA EKONOMSKI RAST}

\section{Teorijski pristup}

Devizni kurs utiče na privredu jedne zemlje na mnogo načina i ostvaruje različite makroekonomske i razvojne uticaje. Frenkel i Tejlor (Frenkel \& Taylor,
2006, 1) izdvajaju oblasti na koje kurs vrši najveći uticaj u zemljama u razvoju i zemljama u tranziciji. To su:

- Alokacija resursa: Kurs ostvaruje značajne efekte na alokaciju resursa u određenom društvu time što utiče na nivo cena. Kako utiče istovremeno na alokaciju resursa i ukupnu tražnju, relativno nizak kurs može da doprinese povećanju zaposlenosti.

- Ekonomski razvoj: Relativno nizak devizni kurs, uz adekvatnu industrijsku i spoljnotrgovinsku politiku, utiče na povećanje konkurentnosti, a time stvara neophodne uslove za povećanje produktivnosti i ekonomski rast.

- Finansije: Sam devizni kurs značajno utiče na očekivanja i ponašanje finansijskog tržišta, što znači da može biti upotrebljen kao mehanizam za njegovu kontrolu i stabilizaciju.

- Tekući bilans: Saldo tekućeg bilansa u velikoj meri zavisi od relativne cene inostranih roba i usluga u odnosu na domaću, odnosno, od realnog deviznog kursa.

- Inflacija: Devizni kurs može da ima ulogu sidra, time što drži cene na relativno niskom nivou putem apresijacije (precenjivanja domaće valute) i njenog održavanja na poziciji čvršćoj od realne.

Najdirektniji uticaj na ekonomski rast jedne zemlje devizni kurs ostvaruje uticajem na spoljnu trgovinu. Hipoteza o ekonomskom rastu zasnovanom na izvozu, izvoznu ekspanziju vidi kao jednu od najvažnijih determinanti rasta zasnovanom na tehnološkom ubrzanju. Jedan od načina na koji spoljna trgovina pokreće ekonomski rast je putem tehnološkog napretka, koji je prirodna posledica međunarodne razmene. Kada je jedna država otvorena za međunarodnu trgovinu i konkuriše na globalnom tržištu, prirodno je da usvaja najnaprednije proizvodne tehnologije i upravljačke tehnike, da angažuje najkvalifikovanije ljudske resurse i ulaže $u$ sofisticirana istraživanja $i$ razvoj (R\&D). Povećanje efikasnosti u pogledu troškova i obima zauzvrat može da unapredi proizvodne faktore - radnu snagu i kapital.

Realni devizni kurs je dobar indikator izvozne konkurentnosti jedne zemlje, pokazujući odnos cena roba $i$ usluga $u$ jednoj $u$ odnosu na cene $u$ drugim 
zemljama. Potcenjenost domaće valute je situacija $u$ kojoj je nominalni devizni kurs iznad realnog, tada govorimo o realnoj depresijaciji. Pri potcenjenom kursu kupovna moć u zemlji je veća nego u inostranstvu. Zbog visoke cene deviza, uvoz poskupljuje, a to dalje dovodi do rasta tražnje za domaćim i opadanja tražnje za uvoznim proizvodima. Izvoznici dobijaju više domaćeg novca, zbog čega raste izvoz proizvoda i povećava se konkurentnost na stranim tržištima. Takva kretanja za posledicu imaju poboljšanje platnog bilansa. Prema tradicionalnoj kejnzijanskoj makroekonomiji, relativna depresijacija podstiče izvoz, čineći ga profitabilnijim, što dalje ohrabruje preduzeća da povećavaju obim svog izvoza. Budući da je tražnja za izvoznim proizvodima relativno elastična $u$ pogledu cena, povećanje obima izvoza vodi ka povećanju izvozne zarade, a time ukupnih prihoda i zaposlenosti.

Nasuprot tome, ukoliko je devizni kurs ispod nivoa realnog deviznog kursa, domaća valuta je precenjena (apresijacija), a strana potcenjena. Precenjenost domaće valute znači da je kupovna moć u inostranstvu veća nego $u$ zemlji. Cene strane robe preračunate $u$ domaću valutu po takvom kursu postaju niže, tako da postoji interes da se roba uvozi, jer uvoz postaje relativno jeftin. Strana roba, koja bi pri realnom deviznom kursu bila previše skupa za prosečnog potrošača, uz niži devizni kurs postaje konkurentna na domaćem tržištu, što, prirodno, vodi smanjenju domaće proizvodnje. I obrnuto, proizvodi koje bi data privreda mogla da izvozi uz realan devizni kurs postaju preskupi, dakle nekonkurentni na stranom tržištu.

Precenjen kurs omogućuje domaćim potrošačima i proizvođačima da se oslone na uvoz, ali veoma negativno utiče na izvozne kapacitete date privrede. $S$ vremenom, uvoz premašuje izvoz i doprinosi odlivu deviza. To, dalje, dovodi do sve manje mogućnosti kupovine roba iz inostranstva i sve teže otplate kredita za servisiranje stranog duga.

Krajnji efekat precenjenog deviznog kursa je da data država gubi raniju komparativnu prednost koju je imala zbog niže cene izvoznih proizvoda $u$ odnosu na konkurentske izvoznice. Naravno, komparativna izvozna prednost ne mora biti niža cena. Ona se može ogledati u boljem kvalitetu ili tehnološki naprednijem procesu proizvodnje. Međutim, ovo je prednost na koju mogu računati razvijene zemlje dok $u$ slučaju zemalja u razvoju, za većinu proizvoda, niska cena predstavlja glavnu prednost.

Čak i u zemljama u kojima je direktan uticaj izvoza na agregatni BDP relativno mali on ostvaruje veliki pozitivan uticaj na druge komponente rasta kao što su investicije i povećanje potrošnje.

Upravljanje deviznim kursom može da ima snažan uticaj na ukupnu štednju s obzirom na to da utiče na potrošnju i investicije putem određivanja realnih nadnica. Niska cena deviza činizaduživanje u devizama relativno jeftinim, što dovodi do prezaduženosti kako zemlje u inostranstvu, tako i građana kod banaka.

Ponekad i sam devizni priliv, koji je, s jedne strane, izuzetno poželjan za svaku privredu, s druge strane, podstiče precenjivanje - apresijaciju deviznih kurseva. Ako se ovako precenjen kurs održava, on može imati za posledicu sputavanje ekonomskog rasta.

Zajednički negativan efekat apresijacije, kao i depresijacije domaće valute, je to što šalju pogrešne signale investitorima o oblastima $\mathrm{u}$ koje treba investirati. U slučaju precenjene domaće valute, proizvodnja oslonjena na uvozne sirovine deluje rentabilnija nego što stvarno jeste. S druge strane, potcenjenost nacionalne valute, usled nerealnog poskupljenja uvoza, šalje signale da treba investirati u sektore koji inače mogu biti rentabilni samo u uslovima nerealno visokog deviznog kursa.

Apresijacija je uvek dobra za ubiranje političkih poena, zato što smanjuje cene uvoznih proizvoda i ima antiinflacioni efekat. Međutim, iz razloga o kojima smo govorili, to može imati razarajuće efekte na alokaciju resursa i perspektive za razvoj. Osim toga, kako je prvi opisao Frenkel još 1983. godine (Frenkel \& Taylor, 2006, 7), fiksni ili kvazi-fiksni snažan kurs može lako da izazove destabilizaciju ciklusa kretanja kapitala.

\section{Empirijska istraživanja}

Empirijska istraživanja uticaja depresijacije na izvoznu zaradu imaju različite rezultate. Neka pokazuju jasnu i direktnu povezanost, odnosno, pozitivan uticaj, dok druga dokazuju da ova povezanost ne postoji. S 
druge strane, istraživanja korelacije između kursa i ekonomskog rasta ukazuju na značajnu povezanost.

Značajno empirijsko istraživanje uticaja dužničke krize u zemljama Latinske Amerike i Istočne Azije sprovedeno je početkom osamdesetih godina 20. veka od strane Saksa (1985, 523-573). Zaključak je bio da su azijske zemlje daleko uspešnije prevazišle ovu krizu upravo zbog boljeg režima deviznog kursa i bolje spoljnotrgovinske politike. Izuzev Filipina, nijedna od uspešnih azijskih privreda nema problem spoljnog duga.

Brojna novija istraživanja donela su dosta dokaza o tome da devizni kurs ima značajan uticaj na rast proizvodnje. Jedna od najznačajnijih je obimna studija Hausmann-a i Eichengreen-a (2005) u koju je uključeno više od 80 slučajeva održivog rasta od 1950-ih (tj, ubrzanog rasta koji je trajao više od osam godina), zatim, istraživanje Razmi-ja (2007), Berg-a i ostalih (2008), Blecker-a i Razmi-ja (2009), i druge studije.

Blecker i Razmi (2009) su ovom problemu pristupili izgradnjom posebnog indeksa deviznog kursa za svaku zemlju-izvoznicu u razvoju u odnosu na:

- valute industrijalizovanih zemalja i

- valute konkurentskih izvoznica u razvoju.

Korišćenjem metode panel podataka, otkrili su da realna depresijacija valute $\mathrm{u}$ odnosu na razvijene zemlje uglavnom daje kontrakcione efekte, ali zato realna depresijacija u odnosu na konkurentske zemlje $\mathrm{u}$ razvoju ima izrazito ekspanzivan uticaj na rast proizvodnje.

Sva navedena empirijska istraživanja dokazuju statistički značajnu ulogu konkurentnih kurseva, kao jednog od nekoliko faktora koji su snažno povezani sa produženim rastom analiziranih privreda.

Ono što se redovno javlja u empirijskim istraživanjima je relativna potcenjenost deviznih kurseva $u$ azijskim zemljama u periodu od 1970. do 2000. godine. U većini radova se, kao regionalni obrazac, javlja niska vrednost domaće valute $\mathrm{u}$ azijskim zemljama $\mathrm{u}$ razvoju.

\section{ISKUSTVA AZIJSKIH ZEMALJA}

Nema sumnje da je trgovina sastavni deo modela rasta zemalja u razvoju. Tokom 20. veka došlo je do ekspanzije spoljne trgovine, što je dovelo do povećanja stope zaposlenosti i generisanja bogatstva, a potom i do drastičnog poboljšanja životnog standarda širom sveta. Mnoge zemlje u razvoju u Aziji sredinom 20. veka, kao što su Južna Koreja i Tajvan, uspešno su usvojile strategiju rasta zasnovanu na izvozu, ostvarile finansijsku ravnotežu i poboljšale produktivnost.

Konkurentne vrednosti azijskih valuta tokom poslednjih 30 godina bile su jedan od najznačajnijih faktora uspešnog rasta zemalja Istočne i Jugoistočne Azije. Oslanjanje na strategiju proizvodnog izvozno orijentisanog rasta dovelo je $\mathrm{u}$ mnogim slučajevima do izuzetnih privrednih uspeha. Zahvaljujući ovakvoj strategiji region Istočne i Jugoistočne Azije u periodu 1960-1980. godine, ostvaruje daleko veći rast od ostalih regiona sveta (Tabela 1), ne računajući Bliski istok, koji je 1970-ih ostvario neuobičajeno visoku stopu rasta zasnovanog na naglom skoku cena nafte. Kako se vidi iz podataka $\mathrm{u}$ Tabeli 1 , $\mathrm{u}$ ovom periodu rast istočnoazijskih privreda iznosio je $6,6 \%$, dok je $u$ razvijenim zemljama bio svega $4,5 \%$, što je bio i svetski prosek. Rast zasnovan na izvozu nastavlja se do kraja 20. veka, mada u poslednje dve decenije Južna Azija, konkretno Indija, ostvaruje veće stope privrednog rasta.

Tabela 1 Rast BDP u regionima sveta 1960-2012.

\begin{tabular}{lccc}
\hline & $1961-1980$. & 1981 - 2000. & 2001-2011. \\
\cline { 2 - 4 } Istočna Azija & 6,6 & 4,1 & 3,6 \\
Razvijene zemlje & 4,5 & 3 & 1,6 \\
Latinska Amerika & 5,5 & 2,3 & 3,4 \\
MENA & 8,7 & 3,0 & 4,4 \\
Južna Azija & 3,7 & 5,4 & 6,9 \\
Svet & 4,6 & 3,1 & 2,5 \\
\hline
\end{tabular}

Izvor: Autor prema podacima Svetske banke (http://databank. worldbank.org) 
Najuspešnije izvozne strategije sproveli su tzv. azijski tigrovi, u koje se ubrajaju Južna Koreja, Tajvan, Hong Kong i Singapur 1970-ih i 1980-ih. Azijski tigrovi započeli su uspon 1960-ih, razvojem industrijske baze i fokusirajući se na međunarodnu trgovinu. $\mathrm{U}$ proizvodnji su imali značajnu prednost $u$ odnosu na razvijene zemlje, zbog relativno niskih nadnica. Tako je početna faza uspona bila obeležena izvozom jeftinih proizvoda lošijeg kvaliteta velikim trgovinskim partnerima, Japanu i SAD. Uz pomoć velikih investicija (domaćih i stranih) i povećanja produktivnosti radnika, ove privrede su vremenom postigle bolji kvalitet robe, ali su nastavile da se oslanjaju na svoju najvažniju konkurentsku prednost, niske cene proizvoda. U nekim slučajevima, azijski tigrovi su koristili i mehanizme kao što su trgovinske barijere, kontrola kursa, kao i druge oblike vladine intervencije kako bi ojačale spoljnu trgovinu kao glavni stub ekonomskog razvoja.

Njihov rast u 1990-im godinama počinje da opada, da bi ulogu vodećih azijskih zemalja u pogledu stope rasta BDP preuzele Kina i Indija. Ove dve zemlje su devedesetih godina prošlog veka maksimalno iskoristile prednosti relativno niskih deviznih kurseva, čime je podstaknut izvoz i rast proizvodnje.

U okviru regiona Istočne Azije, koji već decenijama ostvaruje ubrzani rast, rast kineske privrede $\mathrm{u}$ poslednjoj deceniji je najbrži, u proseku 11\% (Tabela 2). Kineskom privredom uglavnom se upravljalo uz pomoć tradicionalnih makroekonomskih instrumenata kao što su monetarna politika i politika deviznog kursa. Kineska politika deviznog kursa predmet je velikog međunarodnog interesovanja, ali i izvor pritisaka, jer mnogi smatraju da trenutno doprinosi rastu globalne neravnoteže.

Udeo Kine $\mathrm{u}$ svetskoj trgovini je tokom proteklih godina povećan veoma brzo. Ona je najveća izvoznica $\mathrm{u}$ svetu, a njen udeo $\mathrm{u}$ ukupnom svetskom izvozu se i dalje uvećava. U 2010. godini iznosio je više od 10,4\% svetskog izvoza (WTO, World Trade Report 2012, 23). U 2011. godini kineski izvoz je, sa stopom rasta od 9,3\%, bio drugi u svetu po brzini rasta, iza indijskog (WTO, World Trade Report 2012, 21).

Kineska politika deviznog kursa svodi se na održavanje veštački niskog kursa juana kako bi ostvarivala profit od spoljne tražnje i postigla visoke stope rasta.

Od početka ekonomske reforme 1978. godine, u nekoliko navrata je došlo do prilagođavanja kursa juana (Grafikon 1). Januara 1981. godine vlasti $\mathrm{su}$ prepolovile vrednost juana $\mathrm{u}$ trgovinskim transakcijama, uvođenjem interne stope od 2,8 juana za američki dolar dok je zvanični kurs ostao 1,5. U periodu od januara 1981. do kraja 1984. godine vlasti su postepeno depresirale zvanični kurs sve dok nije dostigao 2,8, a tada je ukinuta interna stopa. Međutim, vlasti su nastavile da postepeno devalviraju zvanični kurs, koji je dostigao 3,2 do sredine 1986. godine. Jula 1986. godine vlasti ponovo smanjuju vrednost valute za 15 odsto, a kurs dostiže 3,7 juana za američki dolar.

Tabela 2 Stope rasta privreda Istočne i Jugoistočne Azije 1960-2011.

\begin{tabular}{lcccccccc}
\hline & \multicolumn{1}{c}{} & \multicolumn{1}{c}{ (rast BDP u \%) } \\
Kina & $1960-1980$. & $1980-2002$. & $2003-2006$. & 2007. & 2008. & 2009. & 2010. & 2011. \\
\cline { 2 - 8 } Hong Kong & 4,9 & 9,5 & 11 & 14,2 & 9,6 & 9,1 & 10,4 & 9,3 \\
Indonezija & 9,5 & 5,1 & 8,4 & 6,4 & 2,2 & $-2,8$ & 7,0 & 5,2 \\
Japan & 6,0 & 5,1 & 5,3 & 6,3 & 6,0 & 4,5 & 6,2 & 6,5 \\
Koreja & 7,4 & 2,4 & 2,0 & 2,4 & $-1,2$ & $-5,2$ & 4,4 & $-0,7$ \\
Malezija & 7,8 & 7,1 & 4,1 & 5,1 & 2,3 & 0,2 & 6,3 & 3,6 \\
Singapur & 7,2 & 6,1 & 5,8 & 6,5 & 4,7 & $-1,7$ & 7,2 & 5,1 \\
Tajland & 9,3 & 6,8 & 8,8 & 8,5 & 1,8 & $-1,3$ & 14,8 & 4,9 \\
\hline
\end{tabular}

Izvor: Autor prema podacima Svetske banke (http://databank.worldbank.org) 
Krajem 1989. godine, vlasti ponovo značajno devalviraju zvanični kurs, ovog puta za čitavih 21,2 odsto. Vlada je, potom, napravila nekoliko manjih korekcija $\mathrm{u}$ zvaničnom kursu. Zatim, u januaru 1994. godine, Vlada objedinjava dve stope, a na tržištu preovlađuju cene od 8,7 juana za dolar. Od objedinjenja, juan je dostigao rekordnu vrednost od 8,28 za USD do sredine 1995. godine, a ta vrednost je do danas smanjena na 6,5 juana za jedan američki dolar.

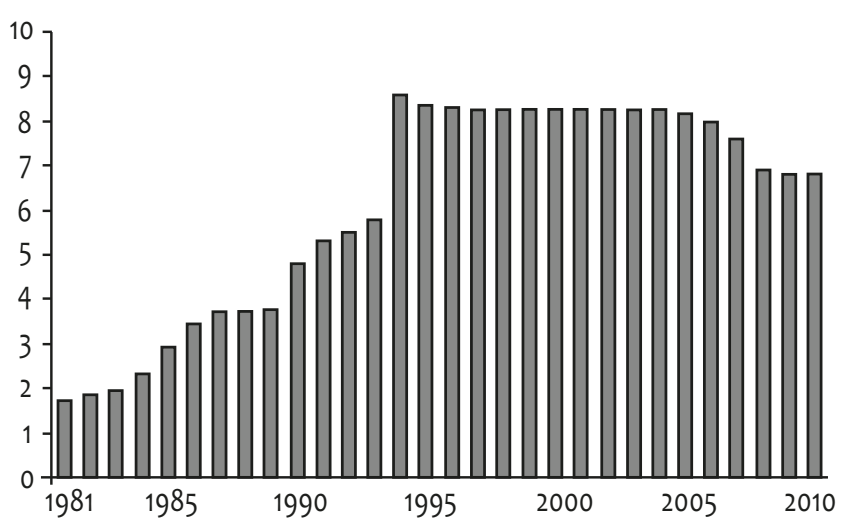

Grafikon 1 Godišnji prosek srednjeg deviznog kursa

Izvor: Autor prema podacima People's Bank of China (www.pbc.gov.cn/publish)

Pitanja deviznog kursa postaju rastući izvor antagonizama na globalnom nivou. SAD i Evropska unija kritikuju Kinu za održavanje depresirane vrednosti juana na nivou potcenjenom i do $40 \%$ u odnosu na dolar. Ovo pitanje, koje preti da izazove trgovinski rat, bilo je na vrhu dnevnog reda na Samitu ministara finansija i guvernera centralnih banaka G 20 koji je održan novembra 2010. godine u Seulu. Ipak, lideri Grupe 20 najvećih privreda sveta odbili su da podrže američki pritisak na Kinu da dozvoli rast vrednosti svoje valute. Na kraju Samita, šefovi Grupe 20 izdali su umereno saopštenje koje se zalaže za uzdržavanje od "konkurentske devalvacije" valuta.

Američki zvaničnici kažu da bi skuplji juan učinio kineski izvoz skupljim, a američku robu jeftinijom u Kini. To bi umanjilo konstantan američki problem deficita $u$ trgovini sa Kinom. Prema podacima U.S. Census Bureau (2010), američki deficit u trgovini sa Kinom je 2010. godine iznosio 273 milijarde američkih dolara, što je novi rekord posle onog iz 2008. godine od 268 milijardi US dolara. Prema podacima iz istog izvora, deficit je još 2002. godine premašio 100 milijardi US dolara i od tada raste neverovatnom brzinom, što je po opštem mišljenju upravo posledica potcenjenog kursa juana. Vašington nije dobio podršku za kritike na račun Kine, verovatno zbog toga što Amerika posle velike ekonomske krize iz 2009. godine sprovodi istu politiku obaranja vrednosti domaće valute. Naime, sledeći odluke američkih federalnih rezervi, konstantno se ubacuju dodatna sredstva od više stotina milijardi dolara u usporenu privredu SAD. Ovim se tržište zasipa dolarima, što obara vrednost američkog novca i daje prednost američkim izvoznicima.

Još jedan podatak koji govori u prilog tezi o pozitivnom uticaju održavanja vrednosti domaće valute na niskom nivou je iskustvo azijskih zemalja sa posledicama azijske krize iz 1997. godine. Zemlje koje su u toku azijske krize iz 1997. godine manje branile kurs svoje valute intervencijama iz deviznih rezervi na kraju su imale manju depresijaciju nacionalne valute i, naravno, manje smanjenje deviznih rezervi od onih centralnih banaka koje su to činile po svaku cenu.

\section{OBELEŽJA SPOLJNE TRGOVINE I POLITIKE DEVIZNOG KURSA U SRBIJI}

Glavna obeležja stanja ekonomskih odnosa Srbije sa inostranstvom su enormni rast spoljne zaduženosti i visok spoljnotrgovinski i platnobilansni deficit, koji se i dalje povećava.

U 2008. godini, uvoz Srbije bio je dva puta veći od izvoza. Prema podacima Zavoda za statistiku Republike Srbije (2011), u toj godini ukupna spoljnotrgovinska razmena iznosila je blizu 34 milijarde dolara, a vrednost izvezene robe samo 11 milijardi. Iako Svetska ekonomska kriza nije dovela do trgovinskog deficita, uslovila je drastičan pad uvoza najvažnijih trgovinskih partnera Srbije, čime je doprinela da se deficit, procentualno, dodatno uveća. Tokom 2009. i 2010. godine deficit se postepeno smanjuje, ali se ukupan izvoz dodatno smanjuje. 
Prema podacima Zavoda za statistiku Republike Srbije, kriza srpskog izvoza traje mnogo duže. U poslednjih deset godina deficit je uvećan sa $-1,75$ na čak $-11,9$ milijardi US dolara u 2008. godini, zatim, smanjen na oko 7 milijardi US dolara u 2009. i 2010. godini, da bi u 2011. ponovo bio uvećan na preko 8 milijardi US dolara, što je činilo rast deficita od oko 16\%. Rastući spoljnotrgovinski deficit je odraz enormnog porasta uvoza u proteklih pet godina, a niskog rasta izvoza. Izvesno povećanje izvoza i smanjenje deficita u 2010. u odnosu na 2009. godinu, prema analizama Zavoda za statistiku Republike Srbije, rezultat je izvoza proizvoda crne i obojene metalurgije, kao i izvoza poljoprivrednih proizvoda, ali i blage depresijacije dinara do koje je došlo 2010. godine.

Tabela 3 Spoljnotrgovinska robna razmena Srbije u periodu 1999-2011.

\begin{tabular}{lrrr} 
& & \multicolumn{2}{c}{ (u milionima US dolara) } \\
\hline Godina & Izvoz & Uvoz & Saldo \\
\hline 1999. & 1369 & 2881 & -1512 \\
2000. & 1558 & 3330 & -1772 \\
2001. & 1721 & 4261 & -2540 \\
2002. & 2075 & 5614 & -3539 \\
2003. & 2755 & 7473 & -4718 \\
2004. & 3523 & 10753 & -7230 \\
2005. & 4482 & 10461 & -5979 \\
2006. & 6428 & 13172 & -6744 \\
2007. & 8825 & 18554 & -9729 \\
2008. & 10973 & 22875 & -11902 \\
2009. & 8344 & 16056 & -7712 \\
2010. & 9,794 & 16,735 & $-6,941$ \\
2011. & 11779,5 & 19861,9 & $-8082,4$ \\
\hline
\end{tabular}

Izvor: Zavod za statistiku Republike Srbije, 2011

$\mathrm{U}$ pogledu razmene sa pojedinim regionima, najveći deficit, mada i najveći obim izvoza, registrovan je u trgovini sa razvijenim zemljama - 988 mil. US dolara, zatim sa zemljama u tranziciji, 859 mil. US dolara dok je sa zemljama u razvoju deficit iznosio 131 mil. US dolara. Ovakva struktura izvoznih tržišta, odnosno, činjenica da najveći deficit imamo sa najrazvijenijim zemljama, potvrđuje pretpostavku o negativnim efektima precenjenosti domaće valute u Srbiji. Uvoz je u Srbiji postao relativno jeftin.

Prema studiji Konkurentnost privrede Srbije (Jefferson Institute, 2006, 1), na osnovu nekoliko sprovedenih istraživanja, Srbija je u mogućnosti da ostvaruje značajno veći izvoz nego što trenutno uspeva. Prema rezultatima ove studije, svi razlozi tog zaostajanja mogu se svesti na zajednički imenitelj, a to je nedovoljna konkurentnost. Srpska privreda je nekonkurentna ne samo $\mathrm{u}$ odnosu na zemlje EU, već i u odnosu na zemlje okruženja. Istraživanje je obuhvatilo ukupno 76 zemalja, a Srbija se po konkurentnosti svoje privrede nalazi na 69. mestu.

Politika jačanja konkurentnosti ne može se razdvojiti od politike deviznog kursa, što je, pored ranije navedenih, dodatni motiv da se ispitaju dometi i mogućnost ovog instrumenta ekonomske politike.

U Srbiji je uvek postojala sklonost ka politici fiksnog nominalnog kursa. Praksa mnogih zemalja pokazuje, a brojna empirijska istraživanja su potvrdila, da fiksni nominalni kurs daje samo kratkoročne rezultate, a da potom dolazi do svih negativnih efekata apresijacije domaće valute - deficit platnog bilansa i prekomerno zaduživanje zemlje. U inflatornim uslovima, "fiksni devizni kurs postaje enormno nerealan, devize postaju potcenjene, a dinar precenjen, što anulira sve pokušaje preduzeća da ostanu konkurentna u izvozu i na domaćem tržištu“ (Kovač, 2006, 15).

Posle političkih promena 2000. godine, Srbija je u određenoj meri napustila politiku fiksnog deviznog kursa, koji je $\mathrm{u}$ tom momentu iznosio neverovatno nerealnih 6 dinara za nemačku marku. Kurs je tada povećan na 30 dinara za marku. Treba naglasiti da ni tada devizni kurs nije bio prepušten tržištu. Određen period je bio, takođe, fiksiran, samo na realnijim vrednostima. Posle 5. oktobra 2000, Narodna banka Srbije (tada još uvek Jugoslavije) koristila je devizni kurs, uz preporuku Međunarodnog monetarnog fonda, za postizanje makroekonomske ravnoteže i smanjivanje inflacije. Dobrim delom u tome se uspelo.

U odnosu na 2000. godinu, "realni efektivni kurs dinara izuzetno mnogo je apresirao u 2001. i 2002. godini" (Kovač, 2006, 16). Uvođenjem nove ekonomske politike 
2001. godine, konstantno je dolazilo do precenjenosti domaće valute. Od 2003. godine na snazi je, bar deklarativno, rukovođeno fluktuirajući režim deviznog kursa. Ovaj model podrazumeva da je devizni kurs tržišno determinisan, a fluktuiranje rukovođeno $u$ smislu povremenog mešanja monetarnih vlasti $u$ tokove deviznog tržišta.

Međutim, iako je model rukovođeno fluktuirajućeg kursa najbliži onom u Srbiji, u proteklom periodu se jasno zapaža učestala intervencija Narodne banke Srbije (NBS) kako bi se održala postojeća vrednost dinara. Time on poprima izvesne odlike (negativne efekte) fiksnog modela.

Monetarna vlast ne bi trebalo da reaguje da bi odbranila određen paritet, već da interveniše relativno retko kako bi ograničila prekomerne destabilizujuće oscilacije deviznog kursa. "Rukovođeno fluktuiranje nacionalne valute na deviznom tržištu ne implicira postojanje unapred objavljene ciljane vrednosti (target) deviznog kursa, te ne postoji potreba monetarnih vlasti da akumuliraju devizne rezerve i njima intervenišu na deviznom tržištu. Samim tim, sa nepostojanjem mete za spekulativne napade, manja je i mogućnost nastanka valutnih kriza“" (Beker, 2006, 31-49).

Prema zvaničnom mišljenju nosilaca ekonomske politike u Srbiji, devizni kurs nije uzrok visokog spoljnog deficita, a nominalni devizni kurs i dalje smatraju sidrom za kontrolisanje inflacije (ovakav stav nameću i međunarodne ekonomsko-finansijske organizacije), bez obzira na njegovu veliku realnu apresijaciju.

Empirijska istraživanja ukazuju na suprotno. Dinar je i dalje konstantno precenjen. Rast domaćih cena je konstantno veći od promene kursa dinara prema US dolaru i euru. "Tek u 2004. godini nastala je blaga realna depresijacija koja nije mogla da ispravi ogromnu kumuliranu apresijaciju. Krajem marta 2005. godine ta kumulativna apresijacija iznosila je 53,48\%" (Kovač, 2006, 16). Prema studiji Macroeconometric Modeling of Serbia's Economy: Theoretical Basis and Results (CES Mecon, 2005), realna apresijacija dinara u navedenom periodu uslovila je većim delom porast uvoza, a manjim delom porast proizvodnje. Centar za ekonomske studije
Mekon pristupio je ekonometrijskom testiranju uvoza u Srbiji koje je pokazalo da na nivo uvoza značajno utiče kretanje realnog deviznog kursa, realnih zarada i industrijske proizvodnje. Ispitivanje uvoza pokazalo je da je devizni kurs u stabilizacionom periodu bio značajni faktor rasta uvoza, a posledično i spoljnotrgovinskog deficita Srbije.

Novije analize, takođe, ukazuju na to da je konstantno precenjen kurs jedan od značajnijih uzroka "ogromnog spoljnotrgovinskog deficita, sve većeg zaduživanja građana, privrede i države..." (Jovović, 2011, 66). Samo u prvoj polovini 2011. godine, dinar je apresirao za 3\% prema euru i $12 \%$ prema američkom dolaru (Jovović, 2011, 74). U aprilu 2011. godine dinar je pao čak ispod 100 dinara, koliko je iznosio i godinu dana ranije. Apresijacija dinara se konstantno odvija bez realnog pokrića, odnosno, bez adekvatnog priliva deviza od izvoza. "Nemoguće je imati jak dinar u slaboj privredi sa malim izvozom..." (Jovović, 2011, 68). Ovo se može pripisati uglavnom samo većim intervenisanjem NBS u predizbornoj godini.

Precenjen kurs dinara i liberalizacija uvoza guše domaću proizvodnju, što ponovo podstiče rast uvoza. Cilj liberalizacije uvoza bio je da se podstakne uvoz novih tehnologija i opreme, koji bi pokrenuli i unapredili proizvodnju u Srbiji. Nažalost, umesto jačanja konkurentnosti domaće proizvodnje na inostranom tržištu, liberalizovan uvoz je doveo do jačanja konkurentnosti inostrane robe na domaćem tržištu, što je dovelo do gašenja velikog broja preduzeća.

Druga navedena slabost precenjene nacionalne valute - prekomerno zaduživanje - takođe je došla do izražaja u Srbiji. Za prezaduženost privatnog sektora zaslužna je velika apresijacija kursa dinara i njegova mnogo veća spoljna od unutrašnje vrednosti. Najveći dug je nastao $\mathrm{u}$ vreme najveće apresijacije $\mathrm{u}$ periodu 2005-2008. godine. Do kraja ovog perioda kurs je dostigao 88,6 dinara za euro, kao posledica događaja na deviznom tržištu krajem godine. Prema podacima Udruženja banaka Srbije (Udruženje banaka Srbije, Konferencija za štampu 18.09.2012.), na kraju 2011. godine 11,8\% dužnika (stanovništva, preduzetnika i pravnih lica) koji su uzeli kredite kod banaka kasni sa otplatom. 
Razlog je, u većini slučajeva, veliko slabljenje dinara u odnosu na euro (sa 79 dinara za 1 euro 2007. godine na 116 din za 1 euro 2012. godine).

$\mathrm{Na}$ osnovu rezultata navedenog ekonometrijskog modeliranja sledi da su osnovni pokretači ekspanzije uvoza i spoljnotrgovinskog deficita od početka 2001. godine, takođe, bili apresijacija realnog kursa dinara i preteran rast domaće tražnje.

Od velikog značaja je i ekonometrijski nalaz da je rast uvoza i spoljnotrgovinskog deficita uslovio ekspanziju domaće tražnje koja već nekoliko godina prevazilazi proizvodnju u Srbiji za $20-25 \%$ sa tendencijom rasta, što je dugoročno neodrživo.

Zahvaljujući relativno visokom kursu dinara, proizvodi iz Srbije su cenovno nekonkurentni u izvozu dok je tražnja za uvoznim proizvodima veća nego što odgovara mogućnostima privrede Srbije. NBS je donedavno isticala da je njen primarni cilj očuvanje inflacije iako se zna da stabilna vrednost nacionalne valute mora da bude rezultat stabilne privrede, a njen rast rezultat rasta produktivnosti, a ne trošenja deviznih rezervi. Da situacija bude još gora, do sada se kurs dinara branio uglavnom pozajmljenim sredstvima. Naime, održavanje dinara na datom nivou posledica je čestog intervenisanja NBS iz deviznih rezervi koje su rezultat privatizacije i zaduživanja spolja, a ne izvoza roba i usluga.

\section{ZAKLJUČAK}

Nekoliko indikatora upućuje na značaj deviznog kursa kao instrumenta ekonomske politike za povećanje izvoza i investicija u Srbiji. U radu se ukazuje na izuzetno pozitivna iskustva istočnoazijskih privreda čija je politika deviznog kursa upravo suprotna onoj u Srbiji. Dodatni razlog za izvozno orijentisanu strategiju razvoja je slabost ionako suviše malog domaćeg tržišta. Treće, faktor koji predstavlja najozbiljniju kočnicu izvozu je izuzetno mala konkurentnost srpskih preduzeća i privrede.

Strategija povećanja konkurentnosti srpske privrede trebalo bi da polazi od tržišne vrednosti deviznog kursa. Realni ili blago depresirani kurs podstakao bi konkurentnost izvoznika i, eventualno, razvoj novih proizvodnih linija koje, u uslovima precenjenog kursa, nisu imale ekonomsku opravdanost.

Da bi se stvorilo konkurentno devizno tržište i formirao devizni kurs koji je rezultat realnih tržišnih odnosa, neophodna je redukcija uloge Narodne banke Srbije na deviznom tržištu. To bi značilo napuštanje dosadašnje politike stabilnosti deviznog kursa, s obzirom na to da je odbrana dinara na ovaj način izuzetno skupa, jer troši devizne rezerve i vodi daljem zaduživanju. NBS bi, u tom slučaju, intervenisala samo povremeno na deviznom tržištu, kada postoji potreba da se spreči ekstremna fluktuacija kursa. NBS treba da preuzme odgovornost za to da se inflacija kreće $u$ određenim okvirima dok određivanje kursa treba da prepusti tržištu.

Srbija danas ima rukovođeno fluktuirajući kurs i po svoj prilici, i po mišljenju većine domaćih i stranih analitičara, to je najbolja solucija. Ima pobornika slobodno plutajućeg, kao i fiksnog deviznog kursa, ali su u značajnoj manjini. Većini je jasno da oba ekstrema imaju brojne slabosti, koje Srbija, sa svojom oslabljenom privredom, teško može da iznese.

Fiksni kurs bi doneo manje kamate, manji rizik i manju neizvesnost poslovanja, ali bi Srbija time iscrpela devizne rezerve. $S$ druge strane, potpuno slobodan kurs, doveo bi do (realnog) pada dinara, što bi u nekom periodu sigurno dovelo do značajnog povećanja izvoza, ali bi posledice po privrednike i građane koji imaju kredite vezane za kurs evra bile katastrofalne.

Kurs bi morao da bude što bliže realnoj vrednosti, a odstupanja od realnog bi morala da imaju tendenciju potcenjivanja, a ne precenjivanja dinara, što bi stimulisalo izvoz, jer samo ekspanzija izvoza može obezbediti Srbiji izlazak iz krize.

Paralelno sa popuštanjem intervenisanja Narodne banke Srbije, zbog eventualnog pada dinara $u$ narednom periodu, trebalo bi da se pristupi problemu ogromnih deviznih kredita građana i preduzeća. U njegovom rešavanju morali bi da učestvuju svi subjekti - dužnici, poslovne banke, predstavnici države, Narodna banka Srbije. 


\section{ZAHVALNICA}

Ovaj rad deo je Projekta osnovnih istraživanja (br. 47004), koji finansira Ministarstvo nauke Republike Srbije.

\section{REFERENCE}

Beker, E. (2006). Devizno-kursni aranžmani - od ekstrema do "normale". Panoeconomicus, 53(1), 31-49.

Berg, A., Ostry, J., \& Zettelmeyer, J. (2008). What makes growth sustained? IMF, Working Paper, Series 08/59.

Blecker, R., \& Razmi, A. (2009). Export-led growth, real exchange rates and the fallacy of composition. Handbook of Alternative Theories of Economic Growth. Northampton.

Frenkel, R., \& Taylor, L. (2006). Real exchange rate, monetary policy and employment. United Nations. New York: Desa Working Paper, No 19.

Hausmann, R., \& Eichengreen, B. (2005). Other People's Money: Debt Denomination and Financial Instability in Emerging Market Economies. Chicago: University of Chicago Press.

Jovović, M. (2011). Dinar i režim deviznog kursa. Bankarstvo, $11-12,56-81$.

Jefferson Institute. (2006). Konkurentnost privrede Srbije.

Kovač, O. (2006). Konkurentnost i politika deviznog kursa u Srbiji. Megatrend revija, 3(1).
CES Mecon. (2005). Macroeconometric Modeling of Serbia's Economy: Theoretical Basis and Results. Beograd.

Razmi, A. (2007). The contractionary short-run effects of nominal devaluation in developing countries: some neglected nuances. International Review of Applied Economics, 21(5), 577-602. Pristupljeno 23.12.2011, http://works.bepress. com/arslan_razmi/4/

Sachs, J. (1985). External debt and macroeconomic performance in Latin America and East Asia. Harvard University, Brookings Papers on Economic Activity. 2, 523-573.

SIEPA. (2010). Invest in Serbia. Beograd.

Učešće docnje $\mathrm{u}$ dugu po osnovu bankarskih kredita. Udruženje banaka Srbije. Pristupljeno 24.09.2012, http:// www.ubs-asb.com/Portals/0/vesti/113/18-09-12-5.pdf

World Trade Report 2012. (2012). WTO.

IMF. World Economic Outlook 2008. Pristupljeno 18.03.2012, www.imf.org/external/pubs/ft/weo/2008/02

People's Bank of China. Pristupljeno 14.05.2011, www.pbc.gov. cn/publish/english/984/index.html

U.S. Census Bureau. Pristupljeno 14.05.2011, www.census.gov/ foreign-trade/balance/c5700.html\#2010

World Bank. Pristupano 14.08.-30.12.2011, www.worldbank. org/

World Trade Report 2012. Pristupljeno 21.09.2012, http://stat. wto.org/CountryProfile

Zavod za statistiku Republike Srbije. Pristupljeno 16.05.2011, webrzs.stat.gov.rs/

Primljeno 25. avgusta 2012,

Nataša Milenković je vanredni profesor na Fakultetu za međunarodnu ekonomiju Megatrend univerziteta u Beogradu. Izvodi nastavu iz nastavnih disciplina Ekonomije Azije i Rusije. Objavila je dva udžbenika, više naučnih radova i učestvovala na nekoliko konferencija u zemlji i inostranstvu. 


\title{
EXCHANGE RATE AS AN INSTRUMENT OF ECONOMIC POLICY - EXPERIENCE OF EASTERN ASIA COUNTRIES
}

\author{
Natasa Milenkovic \\ Faculty of International Economics, Megatrend University in Belgrade, Serbia
}

\begin{abstract}
The main driver of growth in virtually all economies that have achieved rapid growth in recent decades, especially Asian economies, were investment and exports. There is a general agreement that export expansion represents the most effective way for Serbia's economic recovery. The experience of Asian countries, those with rapid growth, can provide guidelines on how the precarious condition of the Serbian economy can be improved to a certain extent. The exchange rate is an instrument of the economic policy that simultaneously affects both the investment and exports of a country, and is the one easier to run than many other factors of growth and development. Several indicators indicate the importance of the exchange rate as an instrument of the economic policy in increasing exports and investments in Serbia. These are, first, the extremely positive experiences of Eastern Asia economies, whose exchange rate policies are the opposite to that of Serbia, the weakness of the domestic market, indicating the necessity of an increase in exports, and thirdly, the extremely low competitiveness of the Serbian enterprises and its economy.
\end{abstract}

Keywords: exchange rate, foreign trade, competitiveness, economic growth, Serbian economy 